\title{
SMJERNICE ZA RAZVIJANJE \\ USLUGA I KORIŠTENJE DRUŠTVENIH MREŽA \\ U NARODNIM KNJIŽNICAMA
}

\author{
GUIDELINES FOR SERVICE DEVELOPMENT \\ AND USE OF SOCIAL NETWORKS IN PUBLIC LIBRARIES
}

\author{
Dunja Holcer \\ Narodna knjižnica i čitaonica Vlado Gotovac Sisak \\ dunjaholcer@gmail.com
}

UDK / UDC 027.022:004.7:658.64

Pregledni rad / Review paper

Primljeno / Received: 18.6.2017.

Prihvaćeno / Accepted: 10.9.2017.

\section{Sažetak}

Cilj. Glavna tema, ujedno i cilj rada, jest predstavljanje Smjernica za razvijanje usluga i korištenje društvenih mreža u narodnim knjižnicama.

Metodologija. U radu su predstavljeni opći statistički pokazatelji korištenja interneta i društvenih medija na globalnoj, europskoj i hrvatskoj razini radi dobivanja slike o okruženju u kojem narodne knjižnice djeluju, a pojašnjeni su i pojmovi „web 2.0“ i „knjižnica 2.0“, uz osvrt na istraživanja koja su se bavila prisutnošću knjižnica na društvenim mrežama te njihovom aktivnošću, kao uvod u predstavljanje Smjernica za razvijanje usluga i korištenje društvenih mreža u narodnim knjižnicama.

Rezultati i praktična primjena. Smjernice su niz temeljnih koraka (faza) osmišljenih tako da pomognu knjižničarima koji se odluče na implementaciju društvenih mreža u usluge knjižnice kod odabira društvene mreže koja će najbolje odgovarati potrebama knjižnice, uz uputu kako trajno razvijati i pratiti napredak usluga knjižnica na odabranoj društvenoj mreži.

Vjesnik bibliotekara Hrvatske 60, 4(2017), 147-159

ISSN 0507-1925

(C) VBH 2017. 
Društveni značaj. Iako prvenstveno namijenjene narodnim knjižnicama, Smjernice se djelomičnom prilagodbom mogu primijeniti i u drugim vrstama knjižnica te na drugim vrstama alata weba 2.0. Njihovom implementacijom knjižnice mogu ostvariti kvalitetniju i svrsishodniju prisutnost na društvenim mrežama, a samim time i osigurati si bolju vidljivost i prisutnost u javnosti, osuvremeniti načine komunikacije i dobiti brzu povratnu informaciju od korisnika.

Originalnost. Smjernice su utemeljene na izvornom znanstvenom istraživanju provedenom za potrebe izrade doktorskog rada i njegov su integralni dio te predstavljaju praktičnu primjenu i doprinos razvoju knjižničnih usluga na društvenim mrežama.

Ključne riječi: društvene mreže, narodne knjižnice, smjernice, web 2.0

\begin{abstract}
Purpose.The main topic, and at the same time the purpose of this paper, is to present the guidelines for the development of library services and use of social networks in public libraries.
\end{abstract}

Methodology. The paper presents the general statistics on the use of internet and social media at the global, European, and Croatian levels in order to obtain a picture of the environment in which public libraries operate. The terms "Web 2.0" and "Library 2.0 " are also explained, with a review of the research dealing with the presence of libraries on social networks and their activities as an introduction to the presentation of the Guidelines for the development of library services and use of social networks in public libraries.

Findings and practical implications. The Guidelines are a series of basic steps (phases) designed to help librarians opting to implement social networks in library services, when selecting a particular social network that best suits a library's needs, with guidance on how to permanently develop and track the progress of library services on the selected social network.

Social implications. Although the Guidelines are intended primarily for public libraries, they can be partially adapted to suit other types of libraries and other types of Web 2.0 tools. With their implementation, libraries can achieve a more quality and more user-friendly presence on social networks, thereby ensuring better visibility and presence in the public, modernization of communication methods, and getting quick feedback from users.

Originality. The Guidelines are based on the original scientific research done for the doctoral thesis and are an integral part of it. They represent practical application and a contribution to the development of library services on social networks.

Keywords: guidelines, public libraries, social networks, web 2.0 


\section{Globalno selo}

Internet čini današnji svijet umreženim. Tvrtke i pojedinci, korporacije, ustanove, nevladine udruge ili pojedine interesne skupine koriste mogućnosti interneta za komunikaciju, marketing, promicanje ideja i suradnju na globalnoj razini. Ono što je omogućilo jačanje i širenje komunikacije i razmjene informacija na internetu ujedno su i njegova dva glavna obilježja - brzina i web 2.0.

Web 2.0 temelji se na društvenoj interakciji u kojoj su sudionici ravnopravni te na kolektivnoj inteligenciji, a pritom je interaktivan i dinamičan, što korisnicima daje ne samo mogućnost da pristupe sadržajima već i da aktivno sudjeluju u njihovu stvaranju. ${ }^{1}$ On integrira cijeli niz tehnologija, društvenih trendova i poslovnih strategija, pri čemu fleksibilan web-dizajn i ponovna upotreba otvaraju mogućnost izrade bogatog korisničkog sučelja „osjetljivog“ na korisnika, olakšavanje zajedničkog kreiranja i razmjene sadržaja, stvaranje novih aplikacija korištenjem onih koje već postoje te uspostavljanje društvenih mreža među ljudima zajedničkih interesa, podržavajući suradnju i pomažući u prikupljanju kolektivne inteligencije. ${ }^{2}$ Zahvaljujući svojim alatima, posebice društvenim medijima, web 2.0 ima široku primjenu u privatnom i poslovnom okruženju.

Dostupni statistički podaci za siječanj 2017. pokazuju kako $50 \%$ svjetskog stanovništva koristi internet, a 37\% koristi društvene medije. Zamjetan je i godišnji porast korištenja interneta ( $10 \%$ u odnosu na siječanj 2016.) te društvenih medija ( $21 \%$ u odnosu na siječanj 2016.). Zanimljivo je i kako je prosječna količina internetskog prometa po jednom ,pametnom telefonu“ 1.9 GB mjesečno te kako je, u odnosu na siječanj 2016., internetski promet na „pametnim telefonima“ porastao je za $30 \%$, čime je u siječnju 2017. činio $50 \%$ ukupnog internetskog prometa. Što se tiče korištenja društvenih medija, na globalnoj razini daleko je najkorištenija jedna od društvenih mreža - Facebook. Na europskoj razini internet koristi $76 \%$ stanovnika, dok se društvenim medijima koristi $49 \%$ stanovništva. $^{3}$

Hrvatska u tom smislu ne zaostaje za ostatkom Europe jer se internetom u Hrvatskoj u siječnju 2017. koristilo 75 \% stanovnika, društvenim medijima njih $47 \%$ (što je porast od $11 \%$ u odnosu na siječanj 2016.), a Facebookom se u tom razdoblju koristilo 200000 stanovnika Hrvatske. ${ }^{4}$

1 Holcer, D.. Hrvatske narodne knjižnice i društvene mreže : doktorski rad. Zagreb : Filozofski fakultet, 2015. Str. 11. [citirano: 2017-06-16]. Dostupno na: http://darhiv.ffzg.unizg.hr/5713/1/ Dunja_Holcer_Doktorski_rad.pdf.

2 Murugesan, S.. Understanding web 2.0. // IT Professional 9, 4(2007). 34 - 41. [citirano: 201706-16]. Dostupno na: http://91-592-722.wiki.uml.edu/file/view/understanding_web_20.pdf.

3 Digital trends 2017: 106 pages of internet, mobile and social media stats. [citirano: 2017-0616]. Dostupno na: https://thenextweb.com/insights/2017/01/24/digital-trends-2017-report-internet/\#.tnw_NoxmvWlb.

4 Digital in 2017: Southern Europe. [citirano: 2017-06-16]. Dostupno na: https://www.slideshare.net/wearesocialsg/digital-in-2017-southern-europe. 
Prema gore prikazanim podacima jasno je kako je način komunikacije i razmjene informacija bilo koje vrste preseljen u mrežno okruženje, a od početka 2017. u mobilno mrežno okruženje. Bilo da se radi o privatnim, obrazovnim ili poslovnim potrebama, internet i alati weba 2.0 mjesto su na kojem će izrazito velik broj ljudi potražiti odgovore, iznijeti mišljenje, podijeliti znanje, razmijeniti informacije, a kako se polovica internetskog prometa odvija putem mobilnih uređaja, može se zaključiti da osobe koje imaju potrebu za nekom vrstom informacija te informacije žele pronaći „sad i odmah“.

S obzirom na brzinu interneta, web 2.0 i njegove alate, mogućnost povezivanja najudaljenijih dijelova svijeta u samo nekoliko sekundi te količinu informacija koje se razmjenjuju, a čiju je količinu gotovo nemoguće izračunati, svijet je doista postao ,globalno selo“5,6 u kojem i knjižničari imaju svoje mjesto i ulogu redefiniranjem knjižničnih usluga i njihovim djelomičnim ,izmještanjem“ u okruženje weba 2.0.

\section{Knjižnice u okruženju weba 2.0}

Načini na koje se dolazi do informacija promijenili su se pod utjecajem interneta i weba 2.0, pa su informacije u velikoj količini postale dostupne u mrežnom okruženju, izašavši tako izvan fizičkih prostora arhiva, knjižnica ili muzeja. Dostupne su većini - uz određenu naknadu ili besplatno - i nalaze se „na samo nekoliko sekundi udaljenosti“, što ima izravan utjecaj i na knjižnice. Knjižničari niz godina pokušavaju naći svoje mjesto unutar okruženja weba 2.0, a knjižnice koje su u svoje poslovanje uspješno integrirale alate weba 2.0 nazivaju se knjižnicama 2.0.

Izraz „knjižnica 2.0“ pojavio se 2005..$^{7}$ unutar knjižničarske blogerske zajednice te je vrlo brzo prihvaćen, no još uvijek ne postoji jednoznačna definicija knjižnice 2.0. Cijeli je niz različitih definicija knjižnice 2.0, pa tako primjerice Casey kaže da je knjižnica 2.0 ,žetva ideja i proizvoda s rubnih područja koji onda mogu biti integrirani u modele knjižničnih usluga za poboljšanje postojećih usluga i stvaranje novih, a zatim nastavak ispitivanja i poboljšavanja tih usluga bez straha da ih se bilo kada zamijeni novijim i boljim uslugama“" ${ }^{\text {" }}$, dok ju Maness

\footnotetext{
5 McLuhan, H. M.. Gutenbergova galaksija : nastajanje tipografskog čoveka. Beograd : Nolit, 1973.

6 Izraz „globalno selo“, koji je skovao Marshall McLuhan, koristi se kao metafora za opisivanje posljedica izazvanih pojavom interneta u smislu brisanja zemljopisnih granica u virtualnom svijetu te mogućnostima komunikacije, razmjene i dostupnosti informacija na globalnoj razini.

7 LibraryChrunch homepage. [citirano: 2017-06-16]. Dostupno na: http://www.librarycrunch. com/2005/09/.

8 Casey, M.. Library 2.0, Beta. 2005. [citirano: 2017-06-16]. Dostupno na: http://www.librarycrunch.com/2005/10/library_20_beta.html.
} 
vidi kao primjenu tehnologija koje su suradničke, interaktivne i multimedijski mrežno bazirane na knjižnične zbirke i usluge, također bazirane na webu. ${ }^{9}$ Sumirajući niz različitih definicija knjižnice 2.0, za Holcer je knjižnica 2.0 „suvremeni oblik knjižničnih usluga koji, koristeći se novim alatima, povezuje stvarni i virtualni prostor, stvarajući interaktivno okruženje u kojem je značajna dvosmjerna i suradnička komunikacija između knjižničara i korisnika." ${ }^{10}$

Da su knjižničari krenuli prema implementaciji alata weba 2.0 u knjižnicama, pokazuje niz istraživanja provedenih u svijetu. Istraživanja su pokazala kako su društvene mreže najzastupljeniji alat, prisutan u svim vrstama knjižnica. Pomoću njih knjižničari ostvaruju dvosmjernu komunikaciju s korisnicima, promoviraju i kreiraju događanja, otvaraju zbirke te nude interaktivnost. ${ }^{11,12,13}$

I u Hrvatskoj knjižničari su započeli s implementacijom alata weba $2.0 \mathrm{u}$ knjižnične usluge i aktivnosti. Ta se implementacija može pratiti od 2009., kada su objavljeni rezultati prvog istraživanja. ${ }^{14}$ Do danas je napravljen niz istraživanja ${ }^{15}$ koja se u najvećoj mjeri bave prisutnošću knjižnica na društvenim mrežama te većinom obuhvaćaju ili samo narodne knjižnice ${ }^{16}$ ili, uz ostale vrste knjižnica, i narodne knjižnice ${ }^{17}$, koje su u smislu mrežnog otvaranja prema korisnicima i naj-

9 Maness, J. M. Library 2.0 theory: Web 2.0 and its implications for Libraries. // Webology 3, 2(2006). [citirano: 2017-06-16]. Dostupno na: http://www.webology.org/2006/v3n2/a25.html.

10 Holcer, D. Nav. dj., str. 34

11 Rogers, C. R. Social media, libraries, and web 2.0: how American libraries are using new tools for public relations and to attract new users - fourth annual survey November 2011. [citirano: 2017-06-16]. Dostupno na: http://dc.statelibrary.sc.gov/bitstream/handle/10827/7271/ SCSL_Social_Media_Libraries_2011.pdf?sequence $=1$.

12 Walia, P. K.; M. Gupta. Application of web 2.0 tool by national libraries // Webology 9, 2(2012). [citirano: 2017-06-16]. Dostupno na: http://www.webology.org/2012/v9n2/a99.html.

13 Kronqvist-Berg, M. Social media and public libraries : exploring information activities of library professionals and users. Åbo : Åbo Akademi University Press, 2014. [citirano: 201706-16]. Dostupno na: http://www.doria.fi/bitstream/handle/10024/94661/kronqvist_maria.pdf?sequence $=2$.

14 Lasić-Lazić, J.; M. Banek Zorica; G. Bubaš. Potential use of web 2.0 tools for library client communication and relationship development. // QQML2009: Qualitative and Quantitative Methods in Libraries, International Conference, Chania, Crete, Greece, 26-29 May 2009. [citirano: 2017-06-16]. Dostupno na: http://www.isast.org/proceedingsQQML2009/PAPERS_PDF/Lasic-Lazic_Zorica_BubasPotential_uses_of_Web_2_tools_for_library_PAPER-QQML2009.pdf.

15 Detaljan popis radova na temu društvenih medija u uslugama hrvatskih knjižnica dostupan je na http://www.hkdrustvo.hr/hr/strucna_tijela/51/publikacije/ [citirano: 2017-06-16].

16 Hebrang Grgić, I.; D. Mučnjak. Social networking phenomenon and its use in libraries = Fenomen društvenih mreža i njegova primjena u knjižnicama. // Croatian Journal of Education 1, 17(2015), 217-241.

17 Hebrang Grgić, I. „Facebook knjižničar“: umijeće komuniciranja na društvenim mrežama // Slobodan pristup informacijama : 12. okrugli stol : zbornik radova. Zagreb : Hrvatsko knjižničarsko društvo, 2013. Str. 33-46. 
zanimljivije jer svojim djelovanjem obuhvaćaju populaciju svih dobnih uzrasta, razina obrazovanja, različitih interesa, profesionalnih usmjerenja i slično.

Ranije provedena istraživanja o prisutnosti hrvatskih narodnih knjižnica na društvenim mrežama bila su polazište za istraživanje provedeno 2013. za potrebe izrade doktorskog rada, koje je obuhvatilo anketiranje ravnatelja/voditelja narodnih knjižnica, anketiranje korisnika u županijskim matičnim knjižnicama, promatranja stvarne aktivnosti narodnih knjižnica na društvenim mrežama, broj i vrste objavljenih sadržaja, vrste pojavnosti kojima su se knjižnice koristile i analizu službenih mrežnih stranica narodnih knjižnica. Zaključci dobiveni iz analize rezultata istraživanja ukazali su, među ostalim, i na to da je razina korištenja informacijsko-komunikacijskih tehnologija u narodnim knjižnicama bila vrlo niska, da većina narodnih knjižnica nije imala aktivne službene mrežne stranice, da većina narodnih knjižnica nije imala nikakvu prisutnost na društvenim mrežama, da narodne knjižnice koje su bile prisutne na društvenim mrežama tu prisutnost nisu koristile u skladu s pravilima proizvođača/vlasnika društvenih mreža, da je Facebook bio najkorištenija društvena mreža, ali je većina prisutnih narodnih knjižnica na njemu bila neaktivna ili slabo aktivna, korisnici narodnih knjižnica nisu bili upoznati s time jesu li knjižnice prisutne na nekoj od društvenih mreža, iako su pozitivnom smatrali moguću prisutnost knjižnica na nekoj od društvenih mreža. ${ }^{18}$

Potaknuta dobivenim spoznajama autorica je, u sklopu doktorskog rada, izradila Smjernice za razvijanje usluga i korištenje društvenih mreža u narodnim knjižnicama ${ }^{19}$, osmišljene kao pomoć pri planiranju, realizaciji, evaluaciji i razvoju usluga narodnih knjižnica na društvenim mrežama. One su i glavna tema ovog rada. Iako su Smjernice prvenstveno predviđene za narodne knjižnice i društvene mreže, djelomičnom prilagodbom mogu se primijeniti u drugim vrstama knjižni$\mathrm{ca}^{20}$, a mogu uključiti ne samo društvene mreže nego i ostale društvene medije i alate weba 2.0.

\section{Smjernice za razvijanje usluga i korištenje društvenih mreža u narodnim knjižnicama}

Pojavnost knjižnice na društvenoj mreži nadopuna je postojećoj službenoj internetskoj stranici knjižnice. Ukoliko knjižnica nema službenu internetsku stranicu, pojavnost knjižnice na promišljeno odabranoj društvenoj mreži može biti

\footnotetext{
18 Holcer, D. Nav. dj.

19 Poglavlje Smjernice za razvijanje usluga i korištenje društvenih mreža u narodnim knjižnicama u potpunosti je i bez izmjena preuzeto iz Holcer, D. Nav. dj. Str. 231-236.

20 Šiptar, D. Društvene mreže u školskim knjižnicama : potencijal i stvarnost : diplomski rad. Zagreb : Filozofski fakultet, 2016. [citirano: 2017-06-16]. Dostupno na: http://darhiv.ffzg.unizg. $\mathrm{hr} / 6878 /$.
} 
dobra, ali privremena alternativa, te bi se trebalo usmjeriti i na to da knjižnica ima i službenu internetsku stranicu. Društvene su mreže vrlo nestalne, zbog čega su knjižnice koje ih koriste umjesto službenih internetskih stranica u stalnoj opasnosti od ukidanja društvene mreže, a čime se gube i svi objavljeni sadržaji te interes javnosti jer se pojavila nova društvena mreža ili nov trend u komunikaciji. Društvene mreže u profesionalnom, knjižničarskom, smislu pružaju mogućnost za ostvarivanje kontakta i s onim osobama koje inače ne posjećuju internetske stranice knjižnice ili ne dolaze u knjižnicu te za stvaranje interaktivnih usluga $u$ virtualnom svijetu, međutim nisu i ne mogu biti adekvatna i potpuna zamjena za službene internetske stranice.

Kao i za svaku drugu novu aktivnost ili uslugu koja se planira provoditi u knjižnici, i za korištenje društvenih mreža potrebno je planiranje i osmišljavanje ciljeva koji će se na taj način ostvariti jer, iako korištenje društvenih mreža neće zahtijevati dodatna financijska sredstva (primjerice uvođenje zbirke i usluga za slijepe i slabovidne osobe zahtijeva dodatna financijska sredstava za nabavu građe i opreme), korištenje društvenih mreža zahtijevat će trajnu angažiranost jednog ili više djelatnika, što treba uzeti u obzir kod planiranja redovne djelatnosti i redovnih aktivnosti knjižnice. Jednako tako potrebno je nakon nekog vremena od implementacije usluga na društvenim mrežama provesti njihovu evaluaciju kako bi se utvrdilo jesu li opravdane i uspješne ili je potrebno promijeniti pristup kako bi se zacrtani ciljevi ostvarili.

Planiranje i provođenje knjižničnih aktivnosti i usluga na društvenim mrežama uključuje nekoliko faza:
a) organizaciju tima
b) istraživanje
c) planiranje ciljeva i aktivnosti
d) identificiranje društvenih mreža koje odgovaraju ciljevima
e) detaljno informiranje o odabranim društvenim mrežama
f) planiranje aktivnosti i usluga
g) pokretanje i razvoj aktivnosti i usluga na društvenim mrežama
h) evaluaciju
i) trajno stručno usavršavanje i eksperimentiranje.

Organizacija tima obuhvaća određivanje djelatnika u knjižnici koji će biti zaduženi za uvođenje, razvoj i održavanje aktivnosti knjižnice na društvenim mrežama. Ako u knjižnici ne radi dovoljno djelatnika da bi se organizirao tim, za uvođenje, razvoj i održavanje usluga na društvenim mrežama može biti zadužena i samo jedna osoba. S planiranjem usluga na društvenim mrežama može se započeti u bilo koje doba godine jer usluge na društvenim mrežama ne zahtijevaju financijska sredstva koja je potrebno unaprijed planirati. 
Sljedeći je korak istraživanje. Istraživanje podrazumijeva pregledavanje društvenih mreža, upoznavanje s njihovim osnovnim karakteristikama, namjenama i mogućnostima, pregledavanje literature o društvenim mrežama i implementaciji društvenih mreža u knjižnične usluge te kontaktiranje s kolegama koje su takve usluge već implementirale kako bi se dobile informacije o mogućim poteškoćama, odnosno prikupila pozitivna i negativna iskustva. S obzirom na veliku dostupnost informacija na internetu, službene internetske stranice knjižnica koje su već uspješno implementirale usluge na društvenim mrežama te aktivne online knjižničarske grupe (primjerice International Librarians Network ${ }^{21}$ ), komunikacija i prikupljanje informacija o iskustvima i ,dobroj praksi“ praktični su i jednostavni. Ta faza trebala bi obuhvatiti i anketiranje korisnika, odnosno ispitivanje javnog mišljenja o pokretanju nove usluge kako bi se utvrdila razina interesa te populacija koja bi takvom uslugom bila najviše obuhvaćena.

Prikupljene informacije služe za detaljnije određivanje ciljeva koji se žele postići implementacijom društvenih mreža u usluge narodne knjižnice i aktivnosti koje bi mogle poslužiti za ostvarivanje tih ciljeva, ali i za identificiranje društvene mreže (ili više njih) koja je pogodna za ostvarivanje zacrtanih ciljeva. Ukoliko je cilj koji se želi postići veća vidljivost u javnosti i lokalnoj zajednici, Facebook i Twitter ${ }^{22}$ mogu biti društvene mreže koje mogu ispuniti takav cilj jer su obje društvene mreže izuzetno popularne među korisnicima interneta. Također, ako je jedan od ciljeva omogućiti dostupnost videozapisa s događanja koja su održana u knjižnici, YouTube ${ }^{23}$ može zadovoljiti takve potrebe i sl. Identificiranjem prema zacrtanim ciljevima određuje se koja je društvena mreža (ili više njih) po svojim karakteristikama najbolja za ostvarivanje tih ciljeva.

Po odabiru društvene mreže (ili više njih) koja će se koristiti, slijedi faza informiranja o odabranim društvenim mrežama. Ta faza predstavlja detaljno informiranje o odabranoj društvenoj mreži, uključujući i iščitavanje pravila koja je postavio osnivač ili vlasnik društvene mreže, kao što su zabrana objavljivanja uvredljivih sadržaja (primjerice sadržaji koji su rasistički, homofobni, pornografski i slično), poštivanje autorskih prava prilikom objave fotografija, umjetničkih reprodukcija, glazbenih i videosadržaja, dijelova književnih tekstova, vrsta pojavnosti namijenjenih ustanovama i sl.

Nakon što je odabrana jedna ili više društvenih mreža koje će se koristiti za potrebe implementacije usluga weba 2.0, slijedi i detaljnije planiranje aktivnosti

\footnotetext{
21 International Librarians Network homepage [citirano 2017-06-16]. Dostupno na: http://interlibnet.org/.

22 Iako je Twitter prvenstveno aplikacija za mikroblogiranje, on se ipak zbog dijela svojih karakteristika ubraja i u društvene mreže.

${ }^{23}$ YouTube je platforma za objavljivanje i dijeljenje videosadržaja, ali se zbog dijela svojih karakteristika ubraja i u društvene mreže.
} 
i usluga koje može biti utemeljeno na prikupljenim informacijama iz faze istraživanja. Također, određuje se i koje će vrste sadržaja biti objavljivane na društvenoj mreži, što znači da se sadržaji mogu ograničiti samo na promoviranje aktivnosti knjižnice i obavijesti koje je potrebno proslijediti korisnicima, fotografije i pozive na događanja ili se mogu proširiti i na zanimljivosti iz kulture i znanosti, obavijesti koje se tiču drugih lokanih ustanova, događanja na lokalnoj razini i slično. U toj je fazi potrebno utvrditi i pravila ponašanja administratora i urednika društvenih mreža te pravila koja se tiču zaštite privatnosti „pratitelja“ pojavnosti društvenih mreža knjižnice, zaštite autorskih prava, korištenja fotografija i videozapisa nastalih tijekom knjižničnih događanja, ali i pravila ponašanja ,pratitelja“ pojavnosti knjižnice na odabranoj društvenoj mreži i slično. Ta se pravila i odluka o sadržajima koji će biti objavljivani objedinjuju u službeni dokument, odnosno pravilnik koji bi trebao biti javno dostupan na službenoj internetskoj stranici knjižnice, kao i na pojavnosti knjižnice na odabranoj društvenoj mreži (ako je odlučeno da se koristi više društvenih mreža, pravilnik bi trebao biti dostupan na svakoj od njih).

Sama provedba pokretanja i razvoj usluga narodne knjižnice na društvenim mrežama započinje otvaranjem pojavnosti knjižnice na odabranoj društvenoj mreži prema pravilima osnivača/vlasnika društvene mreže. Za neke je društvene mreže potrebno da jedan od članova tima otvori privatni profil preko kojeg zatim otvara službenu stranicu knjižnice (npr. Facebook), dok za neke druge društvene mreže to nije potrebno (npr. YouTube). Ostalim članovima tima preko postavki stranice dodjeljuju se administratorske ili uredničke ovlasti kako bi i oni mogli objavljivati sadržaje. Nadalje, prilikom otvaranja pojavnosti na odabranoj društvenoj mreži potrebno je upisati i dodatne informacije o knjižnici (adresu, telefonske brojeve, adresu službene mrežne stranice, radno vrijeme knjižnice, kategoriju, kratak opis poslanja knjižnice, godinu osnivanja knjižnice) te staviti poveznicu na računalni katalog knjižnice i odabrati naslovnu sliku ili tzv. profilnu sliku koja će se pojavljivati uz svaki objavljeni sadržaj.

Po otvaranju pojavnosti knjižnice na društvenoj mreži pristupa se objavljivanju prvih sadržaja te marketingu nove knjižnične usluge. Marketing obuhvaća postavljanje informacije o pojavnosti na društvenoj mreži (ili više njih) na službenu internetsku stranicu knjižnice, usmeno obavještavanje korisnika, izradu promotivnih letaka te slanje poziva putem odabrane društvene mreže na adrese elektroničke pošte onih korisnika koji i inače primaju obavijesti iz knjižnice na taj način. Također, moguće je i da administratori i urednici te ostali djelatnici knjižnice pošalju obavijest svojim ,prijateljima“ koji se koriste istom društvenom mrežom ili da obavijest samo objave na svojim profilima na društvenim mrežama kojima se koriste. Na promoviranju nove usluge potrebno je raditi trajno. 
Narodne knjižnice koje imaju odvojene odjele ili ogranke trebale bi imati samo jednu pojavnost na odabranoj društvenoj mreži. Na taj se način izbjegavaju zabune kod korisnika, a knjižnica djeluje kao jedna cjelina. Za specifične potrebe pojedinog ogranka, kao što je organizacija virtualnog čitateljskog kluba, postoji mogućnost stvaranja grupa otvorenog ili zatvorenog tipa unutar jedinstvene pojavnosti narodne knjižnice. Dječji odjeli narodnih knjižnica također se mogu koristiti grupama za promoviranje i organiziranje posebnih aktivnosti, pazeći pritom na pravila korištenja društvene mreže koja je postavio osnivač/vlasnik društvene mreže (primjerice Facebookom se ne smiju koristiti djeca mlađa od 13 godina, što znači da urednici Facebook-grupe nekog dječjeg odjela moraju pripaziti na to da svi članovi grupe budu stariji od 12 godina).

Narodne knjižnice koje su otvorile pojavnosti koje nisu u skladu s pravilima osnivača/vlasnika društvene mreže moraju promijeniti vrstu pojavnosti. U protivnom, osnivač/vlasnik ima pravo blokirati neispravnu pojavnost knjižnice, čime se gube svi sadržaji objavljeni na društvenoj mreži, kao i kredibilitet kod „pratitelja“ knjižnice. Postupak prebacivanja na ispravnu pojavnost nalazi se u postavkama te vodi administratora korak po korak kako ne bi došlo do gubitka podataka i objavljenih sadržaja.

Što se tiče intenziteta objavljivanja i postavljanja sadržaja na pojavnost knjižnice na odabranoj društvenoj mreži (ili više njih), on treba biti kontinuiran, ali ne i pretjeran. Previše objavljenih sadržaja može odbiti „pratitelje“ jer ih se obasipa informacijama koje ih ne zanimaju. Jedna objava dnevno maksimum je koji bi administratori i urednici trebali poštivati (osim u iznimnim slučajevima). Istovremeno, jedna je objava tjedno minimum jer manje od toga pokazuje da administratori i urednici, a time i sama knjižnica, nisu predani razvoju nove usluge koju su pokrenuli.

Društvene mreže omogućuju neformalnu komunikaciju. Međutim administratori i urednici pojavnosti narodnih knjižnica na društvenoj mreži ne smiju prijeći granicu profesionalnog ponašanja. Neformalna komunikacija omogućava približavanje „pratiteljima“ knjižnice te knjižnicu može učiniti „opuštenijom“ u javnosti, ali postoji granica koja je knjižničarima zadana Etičkim kodeksom ${ }^{24}$ i koju ne bi trebali prijeći. Pojavnost knjižnice na društvenoj mreži jednako je službena kao i službena internetska stranica knjižnice i na njoj treba zadržati profesionalan odnos prema javnosti. Opuštenija je komunikacija dopuštena, ali u granicama zadanim profesionalnim pravilima ponašanja. To se također odnosi i na pravopis, gramatiku i stil izražavanja, koji treba biti u skladu s hrvatskim jezičnim standardom.

24 Etički kodeks Hrvatskoga knjižničarskog društva [citirano: 2017-06-16]. Dostupno na: http:// www.hkdrustvo.

hr/hr/eticki_kodeks/. 
Procjena rezultata usluga na društvenim mrežama, odnosno evaluacija, važna je radi utvrđivanja uspješnosti nove usluge. Društvene mreže u dijelu koji se tiče postavki imaju mogućnost iskazivanja statističkih pokazatelja broja „pratitelja“ stranica tijekom nekog vremenskog razdoblja, jednako kao i statističkih pokazatelja o popularnosti neke objave. Šire mogućnosti statističkog praćenja naplaćuju se. Međutim i smo promatranje ponašanja ,pratitelja“ pojavnosti knjižnice na društvenoj mreži ukazuje na rast i razvoj takve usluge. Anketa korisnika o zadovoljstvu tom uslugom te ispitivanje javnog mišljenja o interesima lokalne zajednice i prikupljanje prijedloga korisnika mogu dati uvid u uspješnost nove usluge i pozitivno utjecati na njezin daljnji razvoj. Evaluaciju bi, nakon pokretanja usluge, trebalo provesti nakon tri mjeseca. Dobiveni rezultati ukazat će na to u kojem je smjeru potrebno krenuti da bi usluga bila što uspješnija, ali će pokazati i moguće nedostatke i greške. Nakon eventualnih izmjena u načinu rada na društvenoj mreži, evaluaciju bi ponovno trebalo ponoviti nakon tri mjeseca. Nakon toga dovoljno je redovito pratiti stanje na pojavnosti knjižnice na društvenoj mreži te povremeno provesti dodatnu evaluaciju.

Nakon što su pokrenuli usluge na društvenoj mreži, administratori i urednici pojavnosti knjižnice trebaju se početi trajno stručno usavršavati. Društvene mreže, kao i svi ostali alati weba 2.0, mijenjaju se i razvijaju velikom brzinom, što od administratora i urednika pojavnosti knjižnice na društvenim mrežama zahtijeva da te promjene i razvoj prate u realnom vremenu. Time se otvara i mogućnost za eksperimentiranje s novim trendovima, uslugama i načinima komunikacije, što pridonosi dinamici posla, ali i pozitivnoj slici u javnosti o knjižnici kao mjestu koje se razvija u skladu s napretkom informacijsko-komunikacijskih tehnologija.

Društvene mreže dio su alata weba 2.0 i stoga su smjernice koje su dane u prethodnom dijelu primjenjive i na primjenu drugih alata weba 2.0, posebno društvenih medija, u uslugama narodnih knjižnica.

\section{Zaključak}

Web 2.0 i njegovi alati omogućili su brisanje fizičkih granica i vremenskih ograničenja koja su do prije nekoliko godina otežavala razmjenu informacija i stvaranje slobodno dostupnih sadržaja. Brzina interneta u kombinaciji s mobilnim tehnologijama koje omogućavaju brz mrežni promet stvara uvjete u kojima oni kojima su informacije potrebne do tih informacija dolaze u nekoliko sekundi, čime su knjižnice dovedene u situaciju da moraju izaći izvan fizičkih okvira i ponuditi sadržaje u mrežnom okruženju. Knjižničari su sada u poziciji u kojoj moraju dopustiti korisničkoj zajednici aktivnije sudjelovanje u promišljanju i stvaranju sadržaja te mijenjati načine pristupa građi (fizičkoj i digitalnoj) i načine na koje distribuiraju informacije iz knjižnica u javnosti. 
Biti tamo gdje je korisnik za knjižnice je izrazito važno, a s obzirom na svoju popularnost, društvene mreže to svakako omogućuju, jer web 2.0 i njegovi alati, poglavito društvene mreže kao njegov najzastupljeniji alat, omogućavaju nadogradnju službenih mrežnih stranica koje su unazad nekoliko godina postale uobičajen i poželjan način komunikacije s javnošću u svim sferama ljudskih djelatnosti, uključujući i knjižnice, te ostvarivanja kontakta s korisnicima na nešto manje formalan način.

Međutim treba uzeti u obzir i to da društvene mreže, kao, uostalom, i svi alati weba 2.0, imaju pravila koja je potrebno poštovati, podložne su naglim ,promjenama raspoloženja“ svojih korisnika, često im osnivači ili vlasnici mijenjaju izgled i mogućnosti, a s obzirom na njihovu brojnost i različite namjene, nije lako odabrati ono što će knjižnici donijeti najbolje rezultate.

Ovdje prikazane Smjernice za razvijanje usluga i korištenje društvenih mreža u narodnim knjižnicama imaju za cilj olakšati i pomoći knjižnicama da na najsvrsishodniji način iskoriste i implementiraju mogućnosti koje im se otvaraju korištenjem društvenih mreža, uz napomenu da su društvene mreže nadopuna, a nikako zamjena za službene mrežne stranice knjižnica.

\section{LITERATURA}

Casey, M. Library 2.0, Beta. 2005. [citirano: 2017-06-16]. Dostupno na: http://www. librarycrunch.com/2005/10/library_20_beta.html.

Digital in 2017: Southern Europe. [citirano: 2017-06-16]. Dostupno na: https://www. slideshare.net/wearesocialsg/digital-in-2017-southern-europe

Digital trends 2017: 106 pages of internet, mobile and social media stats. [citirano: 2017-06-16]. Dostupno na: https://thenextweb.com/insights/2017/01/24/digital-trends-2017-report-internet/\#.tnw_NoxmvWlb

Etički kodeks Hrvatskoga knjižničarskog društva. [citirano: 2017-06-16]. Dostupno na: http://www.hkdrustvo.hr/hr/eticki_kodeks/

Hebrang Grgić, I. „Facebook knjižničar“: umijeće komuniciranja na društvenim mrežama. // Slobodan pristup informacijama : 12. okrugli stol : zbornik radova. Zagreb : Hrvatsko knjižničarsko društvo, 2013. Str. 33-46.

Hebrang Grgić, I.; D. Mučnjak. Social networking phenomenon and its use in libraries = Fenomen društvenih mreža i njegova primjena u knjižnicama. // Croatian Jorunal of Education 1, 17(2015), 217-241. 
Holcer, D. Hrvatske narodne knjižnice i društvene mreže : doktorski rad. Zagreb : Filozofski fakultet, 2015. [citirano: 2017-06-16]. Dostupno na: : http://darhiv.ffzg. unizg.hr/5713/1/Dunja_Holcer_Doktorski_rad.pdf.

International Librarians Network homepage. [citirano 2017-06-16]. Dostupno na: http://interlibnet.org/

Kronqvist-Berg, M. Social media and public libraries : exploring information activities of library professionals and users. Åbo : Åbo Akademi University Press, 2014. [citirano: 2017-06-16]. Dostupno na: http://www.doria.fi/bitstream/handle/10024/94661/kronqvist_maria.pdf?sequence=2.

Lasić-Lazić, J.; M. Banek Zorica; G. Bubaš. Potential use of web 2.0 tools for library client communication and relationship development. // QQML2009: Qualitative and Quantitative Methods in Libraries, International Conference, Chania, Crete, Greece, 26-29 May 2009. [citirano: 2017-06-16]. Dostupno na: http://www.isast. org/proceedingsQQML2009/PAPERS_PDF/Lasic-Lazic_Zorica_BubasPotential_ uses_of_Web_2_tools_for_library_PAPER-QQML2009.pdf.

LibraryChrunch homepage. [citirano: 2017-06-16]. Dostupno na: http://www.librarycrunch.com/2005/09/

Maness, J. M. Library 2.0 theory : Web 2.0 and its implications for Libraries. // Webology 3, 2(2006). [citirano: 2017-06-16]. Dostupno na: http://www.webology. org/2006/v3n2/a25.html.

McLuhan, H. M.. Gutenbergova galaksija: nastajanje tipografskog čoveka. Beograd : Nolit, 1973.

Murugesan, S. Understanding web 2.0. // IT Professional 9, 4(2007). 34 - 41. [citirano: 2017-06-16]. Dostupno na: http://91-592-722.wiki.uml.edu/file/view/understanding_web_20.pdf.

Rogers, C. R. Social media, libraries, and web 2.0: how American libraries are using new tools for public relations and to attract new users - fourth annual survey November 2011. [citirano: 2017-06-16]. Dostupno na: http://dc.statelibrary.sc.gov/bitstream/handle/10827/7271/SCSL_Social_Media_Libraries_2011.pdf?sequence=1

Šiptar, D. Društvene mreže u školskim knjižnicama : potencijal i stvarnost : diplomski rad. Zagreb : Filozofski fakultet, 2016. [citirano: 2017-06-16]. Dostupno na: http:// darhiv.ffzg.unizg.hr/6878/.

Walia, P. K.; M. Gupta. Application of web 2.0 tool by national libraries. // Webology 9, 2(2012). [citirano: 2017-06-16]. Dostupno na: http://www.webology.org/2012/ v9n2/a99.html 